\title{
How Powerful Was the National Policy? The Lesson of the Cotton Mills
}

\author{
MICHAEL N.A. HINTON \\ Minerva's Owl Consulting Economists Ltd \\ and the Rimini Centre for Economic Analysis \\ THOMAS BARBIERO \\ Ryerson University and the Rimini Centre for Economic Analysis \\ MIN SEONG KIM \\ Ryerson University ${ }^{*}$
}

\begin{abstract}
Historians have claimed that Canadian manufacturing grew in the nineteenth century largely because of the National Policy tariff. . In the case of the cotton textile sector, our findings cast serious doubt on the long-standing idea that the National Policy was indispensable to the growth of Canadian manufacturing before WWI.
\end{abstract}

Keywords: National Policy, tariff effectiveness, cotton textile, economic growth

JEL Classifications F11, F13, F14, N61, N71

I found that however simple the plan on which a Protective policy started, it was drawn on irresistibly to become intricate, and to lend its chief aid to those industries which were already strong enough to do without it.

-Alfred Marshall

* Hinton is Chief Economist of Minerva’s Owl Consulting Economists Ltd. and a Fellow at the Rimini Centre for Economic Analysis (RCEA). Barbiero is Professor of Economics at Ryerson University, and also a Fellow at the RCEA. Kim is Assistant Professor of Economics at Ryerson University. This is a revised version of a paper presented at the June 2012 Annual Conference of the Canadian Economics Association and the August 2012 Cities, Open Economies, and Public Policy Conference hosted by the RCEA and the University of Toronto. We thank the participants, and in particular, our discussant at the CEA meetings, Ian Keay, and Almos Tassonyi, who gave an earlier draft a careful reading, for their detailed comments, and suggestions. We are also indebted to many scholars over the years for their advice and criticism, as the paper is based on research Hinton undertook while a doctoral student in economic history at the University of Toronto in the 1980s: particularly, Ian Parker, and the late Ian Drummond, John Dales, and Alan Green.

C Michael N. A. Hinton, Tom Barbiero and Min Seong Kim. Licensed under the Creative Commons Attribution - Noncommercial 3.0 Licence (http://creativecommons.org/licenses/bync/3.0/. Available at http://rofea.org. 


\section{Introduction}

In the conventional interpretation of historians (Bliss 1997), the National Policy tariff was indispensable for the growth of Canadian manufacturing in the nineteenth century. Judging by the leading mainstream economic history textbooks (Marr and Paterson 1980, Pomfret 1993, and Norrie, Owram, and Emery, 2008), however, economic historians consider the question unsettled compared to historians. For example, Dales (1966) appears contradictory in his stance, but overall did not accept a large tariff effect on Canadian manufacturing growth in the second half of the $19^{\text {th }}$ century. Bertram (1963) saw continuous growth of manufacturing in the $19^{\text {th }}$ century Canada, which also leaves little room for the effect of the National Policy on industrial growth.

If we can show through a careful quantitative study of the growth of cotton textiles, an industry that many agree grew because of the National Policy, actually, did not so do, then economic historians would have hard evidence to support their belief that the National Policy was not indispensable and historians may be more easily persuaded that they need to reconsider their position on this important question.

Canada's cotton mills grew at a remarkable 15percent a year between 1870 and 1890, as measured by imports of raw cotton, (see Table 1, below),the output of the industry doubling every five years. Looking around the world at cotton mills in 16 other countries in which modern factory-based cotton mills were to be found, only the Japanese mills grew faster. The cotton mills of Britain and the United States, the oldest and the largest centres of modern cotton textile production, trailed far behind at 2 and 5percent, respectively. ${ }^{1}$

Historians, as McCullough (1991) tells us, have had little good to say about Canada's cotton mills. Partly, we suspect, because historians do not realize how fast the industry actually grew prior to 1879; partly because of their reputation, as harsh, monopolistic, and exploitive employers of labour; and probably, most importantly, because of the deep-seated idea that the National Policy tariff of 1879, or the NP as Victorian Canadians called it, was indispensable to the rapid growth of the cotton mills. ${ }^{2}$

McDiarmid (1946, p. 190) claimed "[cotton textiles] received a substantial impetus from the National Policy.” Naylor (1975, vol. 1, p. P.49) says “[t]he process of domesticating the cotton industry climaxed with the National Policy.” DeLottinville (1980, p. 102) also claims that the "[cotton textiles' growth] was due almost entirely to the [NP] tariff restrictions." Williams (1979), the voice of moderation, referring to the growth of manufacturing generally,

1 For a description of experience of the cotton sectors in other countries and continents see the edited volume by Farnie and Jeremy (2004).

2 McInnis (2000) labels the industry a "laggard" and describes its growth as "meagre," because it did not establish itself in the first half of the nineteenth century. But this is to hold the industry to an unrealistic standard. See Hinton (2012) for an analysis of the relatively late arrival of the cotton industry in Canada. 
HINTON, BARBIERO, KIM The Lessons of the Cotton Mills

remarks, "[w]hile it would be difficult to isolate the tariff as the only, or even the principal cause of ... industrial growth, it clearly played a central role.”

Table 1 Annualized Growth Rates of World's Cotton Mills, in \%

(As measured by raw cotton imports or consumption)

\begin{tabular}{l|c|c|c}
\hline Country & $1870-1890$ & $1890-1910$ & $1870-1910$ \\
\hline UK & 2.2 & 1.0 & 1.0 \\
US & 5.2 & 4.6 & 3.9 \\
Germany & 3.8 & 3.6 & 3.7 \\
Russia & 6.0 & 3.6 & 4.8 \\
France & 1.2 & 3.9 & 2.6 \\
India & $10.0^{*}$ & $3.5^{*}$ & $6.4^{*}$ \\
Austro-Hungary & 4.3 & 3.3 & 3.8 \\
Italy & 10.1 & 3.4 & 6.7 \\
Japan & $19.2^{*}$ & 12.8 & 14.5 \\
Spain & 4.6 & 1.6 & 3.0 \\
Belgium & 3.5 & 4.0 & 3.7 \\
Switzerland & -1.8 & -0.4 & -1.1 \\
Canada & 15.0 & 4.2 & 9.5 \\
Portugal & 8.2 & 3.8 & 5.8 \\
Netherlands & $\mathbf{4 . 5}$ & 4.3 & $\mathbf{4 . 4}$ \\
Finland & $\mathbf{5 . 5}$ & $\mathbf{2 . 9}$ & $\mathbf{4 . 1}$ \\
\hline
\end{tabular}

*Growth in the number of spindles

Source: See Appendix 1.

Michael Bliss's (1987) treatment of the cotton mills growth under the NP from the 1880s to the 1900s in his business history Northern Enterprise is typical of the historical literature's position on the indispensability of protection. ${ }^{3}$ In his narrative Bliss highlights three of a tariff's six possible effects. ${ }^{4}(1)$ From 1879 to 1883 , he says rising profits induced a remarkable increase in output and investment (the production or protection effect). (2) Then, increased domestic production drove out imports (the trade effect). And (3) after 1883, he tells us, when the increased domestic production proved too much for the domestic market to

${ }^{3}$ Bliss 1987, pp.301, 304, and 305. For similar accounts see McCullough 1994, Naylor 1975, Pomfret1993, and Taylor and Baskervile 1994.

${ }^{4}$ Kindleberger 1974 lists 10 effects. Only 6 apply directly to the growth of an industry. The other four are macroeconomic: the terms of trade effect, internal income distribution effect, balance of payments effect, and employment effect. There are of course also the innumerable non-economic effects of a tariff, (see Stigler 1947 for a discussion) that captured the centre of attention in the debate over protection among nineteenth century politicians and which we have no time to consider in this paper. 
absorb, the industry struggled through an over-production crisis. It attempted to escape the crisis by price-fixing cartels, 1883-1889, the dumping of Canadian cloth in foreign markets, and, finally, the orchestration of large-scale, horizontal mergers for monopoly power in1890, 1892, and 1905 (the monopoly effect).

Our interest is primarily with the NP's production or protection effect. We argue that the conventional wisdom among historians rests its case for the power of the NP on an illusion. Cotton textile production was growing fairly rapidly for a short period after the introduction of the NP, but, as we show, it had been growing at a rapid pace for the previous three decades and was in fact an already sizeable sector before the coming of the NP.

Three questions will serve as the organizing framework for our test:

1. How big and how long-established was the industry on the eve of the NP?

2. How protective were the new NP tariffs on cottons?

3. How fast did the industry grow after the introduction of the NP?

\section{How Big and How Long-Established?}

On March 15, 1879, the day the NP went into force, the gross value of output of factory produced cotton textiles in Canada was probably in excess of $\$ 2.5$ million, 5 making it a sizeable domestic manufacture. If other factory-based enterprises were the creation of the NP, “cutlery, clocks, felts, tableware,” says P.B. Waite (1975, p. 138), for example, did not exist before the NP, the same cannot be said for cotton textiles. It was not new to Canada. In Quebec the factory production of cotton textiles had been taking place for 35 years, the first mill being built at Chambly, in 1844, closely followed by one at Sherbrooke. In Ontario cotton mills had been around for 32 years, the first mill being established at Thorold in 1847. In New Brunswick, cotton textiles had been made in factories for 18 years, the first cotton mill opening at Saint John in 1862. Only in Nova Scotia did cotton mills first appear after the $\mathrm{NP}$, the first mill opening at Windsor in 1882. In no other province did cotton mills appear before WWI (Hinton 1990, 1994a, and 1994b).

\section{How Protective Was the NP?}

How much more protective were the 20, 25, and 30 percent, plus, NP duties than the 15 and 17.5 percent revenue tariffs of the 1870 s or the 15 and 20 percent incidentally protective tariffs of the 1850s and 1860s? One way to measure the effective protectiveness of the tariff is to calculate its Barber mark-up: the maximum potential mark-up on the costs of converting

5 Estimated as the average of Urquhart's (1993, p. 389) estimates for “cotton textiles” gross value of product 1878 (\$2.1 million) and 1879 (\$2.9 million). Other manufacturing industries of roughly the same size (\$2 to \$3 million) included distilleries, paper, and railway equipment. 
raw cotton - purchased at world prices -into yarn and cloth. ${ }^{6}$ Typically, Canadian historians have seen the pre-NP tariffs as being low. Firestone (1960, p. 218), for example, says, tariffs "afforded only slight protection to industry" in the 1850s, 1860s, and 1870s. The Barber mark-up tells a very different story. In the early 1850 s, the 12.5 per cent tariff of the day in central Canada delivered a mark-up of 25 per cent. The incidentally protective 20 percent Cayley-Galt tariffs of 1858-59 delivered a mark-up of 68 percent. The 15 percent compromise revenue tariffs of the late 1860s and early 1870s brought the mark-up down to 47 percent. Finally, the 17.5 percent additional protection given by the Liberals last revenue tariff increased the mark-up to 57percent.

With rates of protection like these, and a host of other causal factors at work - such as growth in population and GDP, falling domestic and international transportation costs, the development of factor and product markets, and the invention and diffusion of new machinery and methods in cotton spinning and weaving, such as ring spinning, the power loom and later the automatic loom - one well might expect Canadian cotton textiles to have taken off in a rapid growth spurt as early as the 1850s. And as we will see in the next section this is exactly what happened.

Measuring of the potential protectiveness of the NP is a more difficult task than it is for earlier tariffs because the NP tariff was more complicated schedule, but it is simple enough to get a clear idea of the possible range of protectiveness by measuring the Barber mark-up delivered by ad valorem equivalent NP tariff ranges of 20, 25, 30, and 35percent, which covers the full range of imported cotton goods competing with the goods produced by Canadian mills and, then, compare these mark-ups to those delivered by the older so-called revenue or incidentally protective tariffs. The maximum potential Barber mark-up, assuming conservatively the cost share of raw cotton to domestic firms was 0.5 (see Hinton 2012), comes to 40 percent for goods paying 20 percent, 50 percent for goods paying 25 percent, 60percent for goods paying 30 percent, and a whopping 70 percent for goods, like prints in 1884, paying 35 percent. ${ }^{7}$ With maximum potential rates of protection like these it is no wonder there was a mad rush to invest in cotton mills in the early 1880s. ${ }^{8}$ But it is also

${ }^{6}$ See, Barber 1952, Dales 1964, and Mackintosh 1937. We are indebted to a paper by Harley (2001) for reminding us of this simple and elegant approach to measuring protectiveness. The mark- up, it is easy to show, is equal to the ad valorem or ad valorem equivalent tariff, $t$, divided by $1-S c(1+t)$, where $S c$ is the Canadian industry's cost share of raw cotton, which was in 1870 (see Hinton 2012) just under 60 percent.

7 According to the Census of 1870 the share of raw cotton costs in the gross value of production of cottons was 0.59 .

8 Inwood and Keay(2013) point out the NP also led to new capital investments in the iron and steel industry. 
possible, as we have suggested, that the tariffs of the late 1850s were so high as to be to a large extent redundant and by the late 1870s almost entirely or completely so. That is, it is possible that the rate of protection remained unchanged despite the decreases in the tariff at Confederation and then the increases that climaxed with the NP. But before we go any further into causes, let us examine the actual growth of the cotton mills more closely.

\section{How Fast Did the Industry Grow?}

If the NP was indispensable to the growth of domestic cotton textiles, as Canadian historians suggest, one would expect to find a growth spurt in or around 1879.. Indeed if there is any break point in these measures of long term growth it is not on or about 1879, but on or about 1883, four years later, when the so-called overproduction crisis struck, and the curve of growth tilts down.

What follows is a structural change test to determine whether there was a structural change in the growth rate of the domestic cotton textile mill industry, and thus try to ascertain how much of an impact the NP had on the growth of the cotton textile sector after it was introduced.

In this section, we investigate whether there exists a structural change in the growth rate of domestic cotton mill industry in or around 1879 when the NP tariff was introduced. Using the time series of domestic cotton mill production input deflated by a Canadian cotton goods price index, we conduct the structural change tests based on the following trend function:

$$
\begin{array}{r}
\log Q_{t}=\mu_{0}+\beta_{0} t+\mu_{1} I\left(t \geq T_{0}\right)+\beta_{1} t I\left(t \geq T_{0}\right)+\varepsilon_{t}=X_{t}^{\prime} \Psi+\varepsilon_{t} \\
\mathrm{t}=1850, \ldots, 1913
\end{array}
$$

where $X_{t}=\left[1, t, I\left(t \geq T_{0}\right), t I\left(t \geq T_{0}\right)\right]^{\prime}$ and $I\left(t \geq T_{0}\right)$ is the indicator function which is equal to one if $t \geq T_{0}$ and zero otherwise. Thus, $\beta_{0}$ and $\beta_{0}+\beta_{1}$ represent the average growth rates of the real input in 1950 $\left(T_{0}-1\right)$ and $T_{0} \sim 1913$ respectively, and $T_{0}$ is the point that the structural change in the growth rate may occur. We consider the null hypothesis

$$
H_{0}: \beta_{1}=0
$$

which implies no structural change at $T_{0}$. While we introduce $\mu_{1}$ and $\beta_{1}$ to parameterize the structural change in the trend function, we construct the null hypothesis only about $\beta_{1}$ because our interest is in the growth rate.

There is large literature on the structural change test in statistics and econometrics. Among recent works, we employ the test procedure developed by Perron and Yabu (2009). The test is based on the feasible GLS transformation with modification as follows:

$$
\left(1-\hat{\alpha}_{s} L\right) \log Q_{t}=\left(1-\hat{\alpha}_{s} L\right) X_{t}^{\prime} \Psi+\left(1-\hat{\alpha}_{s} L\right) \varepsilon_{t}
$$


HINTON, BARBIERO, KIM The Lessons of the Cotton Mills

where $L$ is the lag operator,

$$
\begin{aligned}
& \hat{\alpha}_{s}=\hat{\alpha} I\left(T^{\delta}|\hat{\alpha}-1>d|\right)+I\left(T^{\delta}|\hat{\alpha}-1 \geq d|\right) \\
& \hat{\alpha}=\sum_{t=2}^{T} \hat{\varepsilon}_{t} \hat{\varepsilon}_{t-1} / \sum_{t=2}^{T} \hat{\varepsilon}_{t-1}^{2}
\end{aligned}
$$

and $\left\{\hat{\varepsilon}_{t}\right\}$ are the OLS residuals based on (1).

We test the structural change in two different ways. First, we impose the structural change point when the NP tariff was introduced $\left(T_{0}=1879\right)$. Perron and Yabu (2009) show that when the structural change point is known $W_{F S}(\lambda)$ defined in (4) converges in distribution to a $\chi^{2}(1)$, not only when $\varepsilon_{t}$ is stationary $(|\alpha|<1)$ but also when it has a unit root $(|\alpha|=1)$. That is, we have

$$
W_{F S}(\lambda)=[R(\widehat{\Psi}-\Psi)]^{\prime}\left[S^{2} R\left(\sum_{t=1}^{T} X_{t} X_{t}^{\prime}\right) R^{\prime}\right]^{-1}[R(\widehat{\Psi}-\Psi)] \rightarrow^{d} \chi^{2}(1)
$$

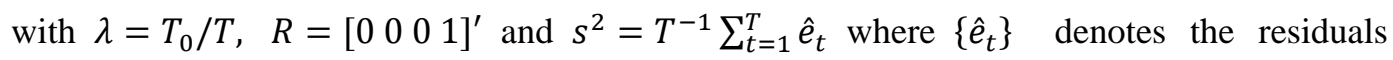
associated with (2). Regarding the choice of $\delta$ and $d$ in (3), we use $\delta=0.5$ and $d=1$ as suggested by Perron and Yabu (2009). The result of test is summarized in Table 2 and Figure 1.

Table 2 illustrates that given the structural change point in 1879, the change in growth rate is significant even at $1 \%$ level $\left(W_{F S}(\lambda)>\chi_{0.99}^{2}(1)=6.63\right)$. It is interesting, however, that the cotton mill industry actually experienced significant decline in growth after the NP was introduced. The average annual growth rate was decreased from $16.1 \%$ to $5.3 \%$. Figure 1 also clearly shows the decrease in growth rate since 1879. This finding is a very strong evidence against the conventional wisdom of historians that the growth of Canadian cotton mill industry in the second half of the $19^{\text {th }}$ century is mainly attributable to the NP tariff.

Table 2: Annual growth rate of real input index of cotton mills output (1850 1913) with a structural change in 1879

\begin{tabular}{|l|c|c|c|}
\hline & \multicolumn{2}{|c|}{ Annual growth rate } & \\
\hline Break point & Pre & Post & $W_{F S}(\lambda)$ \\
\hline 1879 & $16.1 \%$ & $5.3 \%$ & 42.3 \\
\hline
\end{tabular}


Figure 1: Growth of real input index of cotton mills output with a structural change in 1879

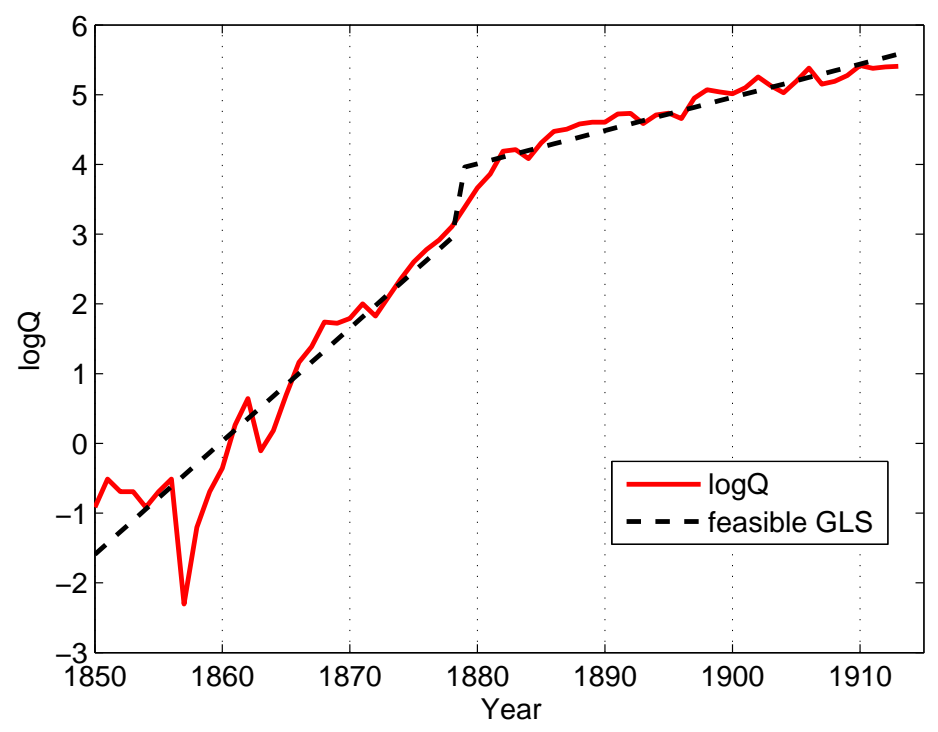

Now, we conduct the test without imposing a specific change point. In this case, the change point is estimated from the data. Based on (2), we construct the following test statistic:

$$
\operatorname{Exp}-W_{F S}(\lambda)=\log \left[\frac{1}{T} \sum_{\Lambda} \exp \left(\frac{1}{2} W_{F S}(\lambda)\right)\right]
$$

where $\Lambda=\{\lambda: \epsilon \leq \lambda \leq 1-\epsilon\}$ for some $\epsilon>0$. When the structural change point is unknown, the limiting distribution of $\operatorname{Exp}-W_{F S}(\lambda)$ is nonstandard, but can be calculated by simulations. We use $\epsilon=0.25$, in which case the critical values are provided in Perron and Yabu (2009). The result of the test is summarized in Table 3 and Figure 2.

Table 3: Annual growth rate of real input index of cotton mills output (1850 1913) with an unknown structural change point

\begin{tabular}{|l|c|c|c|}
\hline & \multicolumn{2}{|c|}{ Annual growth rate } & \\
\hline Break point & Pre & Post & $\operatorname{Exp}-W_{F S}(\lambda)$ \\
\hline 1883 & $16.4 \%$ & $4.3 \%$ & 25.5 \\
\hline
\end{tabular}




\section{HINTON, BARBIERO, KIM The Lessons of the Cotton Mills}

The break point is estimated by minimizing the sum of squared residuals from (1). As shown in Perron and Zhu (2005), estimating the break point in this way yields a consistent estimate whether $\varepsilon_{t}$ is stationary or has a unit root. The findings from this test are very similar to the ones with known change point. $\operatorname{Exp}-W_{F S}(\lambda)$ is larger than the critical value (=5.58) at $1 \%$ level, so we can reject the null hypothesis with strong confidence. We can also see that there was a remarkable decline in the growth rate of the cotton textile sector in the early 1880s, when there was overproduction crisis in the Canadian cotton textile industry. Indeed, these results almost turn the conventional wisdom among historians on its head: soon after the introduction of the NP the growth of the cotton textile sector actually slowed down compared to the previous three decades.. There may have been other reasons that its rate of expansion slowed down, but this is an unexpected occurrence if the NP supposedly drove its growth.

Figure 2: Growth of real input index of cotton mills output with an unknown structural change

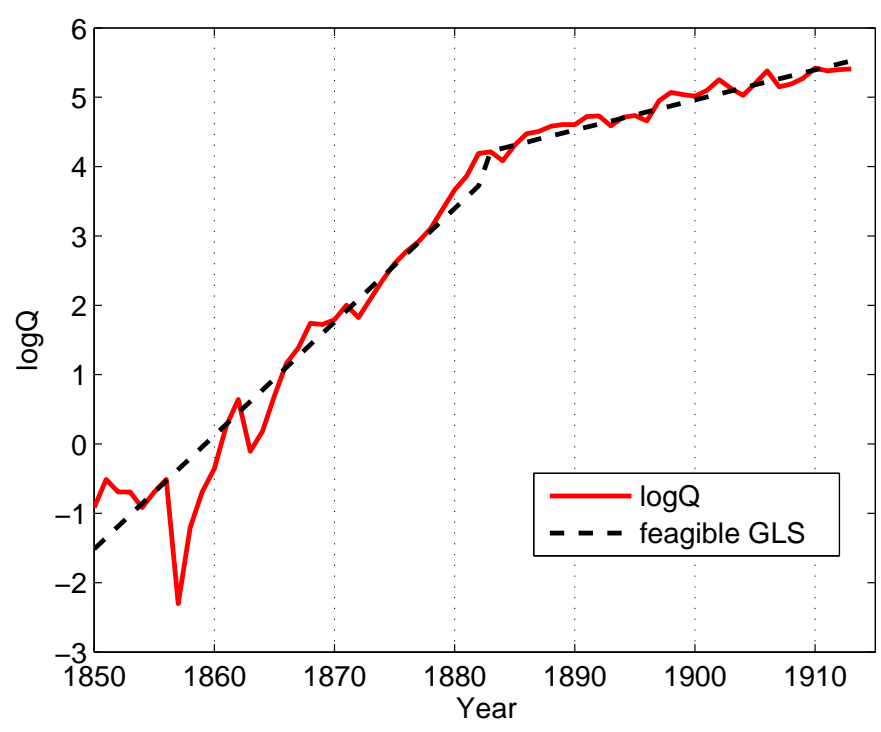

\section{What Are The Lessons?}

There is still an ongoing debate on the role of tariffs on the growth rate of manufacturing in the $19^{\text {th }}$ century. For example, O’Rourke (2000) found tariffs to be positively correlated with growth in many countries, including Canada, in the period between 1875 and 1914. On the other hand, we noted above that Dales (1966) and Bertram (1963) were sceptical of the tariff effect on Canadian manufacturing output in $19^{\text {th }}$ century Canada. Of course, correlation does 
not necessarily imply causation and addressing the causes of growth of the manufacturing sector in general can hide different factors affecting the growth rate of different sectors at in different periods. By focusing on just the cotton textile sector in $19^{\text {th }}$ century Canada, we have been able to get a closer glimpse of its dynamics and development prior to the onset of the NP and compare it with the post-NP growth performance. We saw that the cotton textile sector did indeed enjoy quite a bit of effective tariff protection in the 30 some odd years prior to the introduction of the NP and but it is from certain the extent to which this protection stimulated its growth.

The Canadian cotton textiles output grew rapidly, increasing at rate of 17-18 per cent a year from 1850 to 1883 and then at a more moderate 4.0 to 4.4 per cent a year from1884 to 1914. Our structural change test shows that this decline in the growth rate was substantial. Canadian historians have long claimed that the cotton industry's growth depended largely on the NP We find, however, that the NP tariff was a relatively unimportant causal factor in the growth of the industry. Because:

1. The Canadian cotton textile industry was a sizable industry before the coming of the NP whose trend growth was significantly faster before the NP than after.

2. The pre-NP "revenue” tariffs offered a much higher potential level of protection than historians have realized. As a result, the NP increased tariff rates, but may not have increased the actual rate of protection as the tariffs of the 1870s.

The fundamental lesson of Canada's cotton mills is that, the NP tariff increases of 1879 had little to do with the industry's rapid growth. Our analysis has shown how easy it is to fall into the post hoc, ergo propter hoc pitfall in reasoning. We know that tariffs do distort domestic price signals and the natural conclusion is to assume that tariffs help increase the output of protected domestic industries. However, the cotton textile sectoralready enjoyed protection from foreign competition prior to the coming of the NP. Hinton and Barbiero (2012) elsewhere cast doubt on the effectiveness of tariff protection on the Canadian cotton textile industry even prior to the institution of the NP.

Perhaps another lesson to be learned by our exercise is the importance of disaggregated analysis to get a better understanding of causal factors in economic growth. While analysing the growth of the manufacturing sector as a whole can lead to some overall insights as to the causes of economic growth, sectoral analysis is instrumental understanding the particular forces that contributed to the growth, or the lack there of, of an industry in different time periods. 
HINTON, BARBIERO, KIM The Lessons of the Cotton Mills

\section{Appendix: A Note on Statistical Sources}

\section{Table 1:}

Annualized rates of growth are calculated between calendar years, or calendar year equivalents, 1870, 1890 and 1910. U.S. data refers to raw cotton consumption and is taken from United States, Bureau of the Census. 1975. Historical Statistics of the United States. Washington, D.C.: GPO; European data refer to imports of raw cotton and are taken from B.R. Mitchell. 1975. European Historical Statistics, 1750-1970. London: Macmillan; Indian data is raw cotton consumption and is taken from B. R. Mitchell. 2003. International Historical Statistics: Africa, Asia, and Oceania, 1750-2000. New York: Palgrave Macmillan; Japanese data is raw cotton imports and is taken from S.J. Koh. 1966. Stages of Industrial Development in Asia: A comparative history of the cotton industry in Japan, India, China, and Korea. Philadelphia: University of Pennsylvania Press, Appendix, Table 1; Canadian data is imports of raw cotton taken from Canada's Tables of Trade and Navigation.

\section{Data series used in the regression:}

$\mathrm{Q}$ is a real output of cotton goods index $(1890=100)$ for which we have two measures: The money value of output of cotton goods taken from Urquhart (1993) deflated by a domestic cotton goods price index, $\mathbf{P}$, (see below) and expressed in index number form; and our real input index based on our estimates of the quantity imports of raw cotton (pounds) into the Province of Canada and New Brunswick (1850-1867) and the Dominion of Canada (18681913) from the Tables of Trade and Navigation of the provinces of Canada and New Brunswick and The Dominion of Canada.

\section{References}

Acheson, T.W. (1972), The National Policy and the Industrialization of the Maritimes, .Acadiensis 1, 2 (Spring), 1-28.

Bairoch, P. (1989), European Trade Policy, 1815-1914. In Cambridge Economic History of Europe, vol. 3, edited by Peter Mathais and Sydney Pollard. Cambridge: Cambridge University Press.

Barber, Clarence L. (1955), Canadian Tariff Policy. Canadian Journal of Economics and Political Science 21, 4 (November), 513-30.

Barnett, D.F. (1976), The Galt Tariff: incidental or effective protection. Canadian Journal of Economics 9, 3 (August): 389-407.

Bertram, G.W. (1963), Economic Growth in Canadian Industry, 1870-1915: The Staple Model and the Take-Off Hypothesis. The Canadian Journal of Economics and Political Science, 29,2(May): 159-184. 
Bils, Mark. (1984) Tariff Protection and Production in the early U.S. Cotton Textile Industry. Journal of Economic History 44, 4: 1033-45.

(1974) A Living Profit: Studies in the Social History of Canadian Business, 1883-191. Toronto: McClelland and Stewart.

(1987) Northern Enterprise: Five Centuries of Canadian Business. Toronto: McClelland and Stewart.

Canada (1874), Census of Canada, 1870-71. Vol. 3.

Canada, 1879-1884.House of Commons.1878-83.Debates.

Canada. (1938), Report of Royal Commission on the Textile Industry.

Clark, Gregory (1987), Why Isn't the Whole World Developed? Lessons from the Cotton Mills, Journal of Economic History 47, 1 (March): 141-173.

Dales, John H. (1966), The Protective Tariff in Canada's Development. Toronto: University of Toronto Press.

David, Paul (1970), Learning By Doing and Tariff Protection: A Reconsideration of the Case of the Ante-Bellum United States Cotton Textile Industry. Journal of Economic History 30, 3 (September): 521-601.

Davis, Lance and H. Lewis Stettler III (1966), The New England Cotton Textile industry, 1825-1860: Trends and Fluctuations. In Output, Employment, and Productivity in the United States after 1800. Studies in Income and Wealth, vol. 30, pp. 213-38 (New York: National Bureau of Economic Research).

DeLottinville, Peter (1980), Trouble in the Hives of Industry: The Cotton Industry Comes to Milltown, New Brunswick, 1879-1892. Historical Papers / Communications historiques 15, 1: 100-115.

Dick, Trevor J. O (1982), Canadian Newsprint, 1913-1930: National Policies and the North American Economy, Journal of Economic History 42, 3 (September): 659-87.

Eastman, H.C. and S. Stykolt (1967), The Tariff and Competition in Canada. Toronto: Macmillan of Canada.

Farnie, D. and Jeremy, D. (eds.) (2004). The Fibre that Changed the World: The Cotton Industry in International Perspective, 1600-1990s. Oxford University Press

Firestone, O. J (1958), Canada's Economic Development, 1867-1953,.Income and Wealth Series VII. London: Bowes and Bowes.

Fogel, R. W.And S. L. Engerman (1969), A Model for the Explanation of Industrial Expansion during the Nineteenth Century: With an Application to the American Iron Industry. Journal of Political Economy 77(): 306-28.

Forster, Ben (1979), The Coming of the National Policy: Business, Government and the Tariff,. Journal of Canadian Studies, (Autumn): XXX.

Forster, Ben (1986), A Conjuncture of Interests: Business, Politics, and Tariffs, 1825-1879. Toronto: University of Toronto Press. 
HINTON, BARBIERO, KIM The Lessons of the Cotton Mills

Fowke, V.C (1952), The National Policy - Old and New. Canadian Journal of Economics and Political Science 18, 3 (August): 271-286.

Harley, C. Knick (1992), International Competitiveness of the Antebellum American Cotton Textile Industry. Journal of Economic History 52, 3: 559-84.

(2001), The Antebellum Tariff: Different products or Competing Sources? A Comment on Irwin and Temin. Journal of Economic History.61: 799-805.

Hinton, M.N.A (1990), Corporate Concentration in the Cotton Industry, Historical Atlas of Canada, Vol. III, Toronto, University of Toronto Press, Plate 7, The Changing Structure of Manufacturing.

Hinton, M.N.A. (2012), How Powerful was the National Policy? The Lesson of the Cotton Mills. Department of Economics, Ryerson University. Working Paper 37.

(1994), Gault, Andrew Frederick, Dictionary of Canadian Biography, Vol 13, 1901-1910. Toronto: U of T Press, pp. 372-376.

(1994), Parks, John Hegan, Dictionary of Canadian Biography, Vol 13, 19011910. Toronto: U of T Press, pp. 813-815.

(2011), Was Canadian Manufacturing Inefficient Before WWI: The Case of the Cotton Textile Industry. Working Paper44-11, Rimini Centre for Economic Analysis.

(2012), Infant Industry Protection and the Growth of Canada's Cotton Mills: A Test of the Chang Hypothesis. Working Paper 55-12, Rimini Centre for Economic Analysis. Forthcoming in: Markets, Firms, and States: Strategic Globalization and Canadian Business and Economic History. Edited by Dimitry Anastakis and Andrew Smith. Toronto: University of Toronto Press, 2013.

Hinton, M.N.A. and T. Barbiero. (2012), Does the National Policy Explain the Growth of Canada's Cotton Mills? Working Paper 36, Department of Economics, Ryerson University.

Inwood, Kris E (1991), Maritime Industrialization from 1870 to 1910: A Review of the Evidence and Its Interpretation. Acadiensis21, 1 (Autumn): 132-55

Inwood, K. and Ian Keay (2005), Bigger Establishments in Thicker markets: Can We Explain early Productivity Differentials. Canadian Journal of Economics 38, 4 ():1327-63

(2013), Trade Policy and Industrial Development: Iron and Steel in a Small Open Economy, 1870-1913. Canadian Journal of Economics 46, 4 (November):1265-94

Irwin, Douglas A (1996), Against the Tide: An Intellectual History of Free Trade. Princeton: Princeton University Press.

(2000), Did Late-Nineteenth-Century U.S. Tariffs Promote Infant Industries?

Evidence from the Tinplate Industry. Journal of Economic History 60, 2 (June): 335-36. (2001), Tariffs and Growth in Late Nineteenth Century America. The World Economy 24 (January): 15-30. 
(2002), Interpreting the Tariff-Growth Correlation in the Late Nineteenth Century. American Economic Review 92 (May): 165-169.

Irwin, Douglas A. and Peter Temin (2001), The Antebellum Tariff On Cotton Textiles Revisited. Journal of Economic History 61: 777-98.

Macintosh, W. A (1939; 1964), The Economic Background of Dominion Provincial Relations: Appendix III of the Royal Commission Report on Dominion-Provincial Relations, edited and introduced by J.H. Dales. Toronto: McClelland and Stewart.

McCullough, A.B (1991), The Primary Textile Industry in Canada: History and Heritage. Ottawa: National Historic Sites, Park Canada, Environment Canada.

McDiarmid, O. J (1946), Commercial Policy in the Canadian Economy. Cambridge, Massachusetts: Harvard University Press.

McGouldrick, Paul F (1968), New England Textiles in the Nineteenth Century: Profits and Investment. Cambridge, Mass.: Harvard University Press.

McInnis, R. Marvin (2000), The Economy of Canada in the Nineteenth Century.`In The Cambridge Economic History of the United States: The Long Nineteenth Century, edited by Stanley L. Engerman and Robert E. Gallman, pp. 57-108. Cambridge: Cambridge University Press.

Naylor, R.T (1975), The History of Canadian Business, 2 vols. Toronto: James Lorimer.

Norrie, K.H (1979), The National Policy and the Rate of Prairie Settlement: A Review. Journal of Canadian Studies 14, 3 (Fall): 63-76.

Norrie, Kenneth, Douglas Owram, and J. C. Herbert Emery (2008), A History of the Canadian Economy, fourth edition. Toronto: Thomson-Nelson.

O’Rourke, Kevin H (2000), Tariffs and Growth in the Late $19^{\text {th }}$ Century. Economic Journal 110, 463 (April): 456-483.

Marr, William L. and Donald G. Patterson (1980), Canada: An Economic History. Toronto: Macmillan.

Perron, Pierre and Yabu, Tomoyoshi (2009), Testing for Shifts in Trend with an Integrated or Stationary Noise Component. Journal of Business and Economic Statistics 27(3): 369-396.

Perron, Pierre and Zhu, Xiaokang (2005), Structural Breaks with Deterministic and Stochastic Trends, Journal of Econometrics 129: 65-119.

Pomfret, R (1993), The Economic Development of Canada. Second edition. Scarborough, Ontario: Nelson.

Robson, R (1957), The Cotton Industry in Britain. London: Macmillan.

Sandberg, Lars (1974), Lancashire in Decline: A Study of Entrepreneurship, Technology and International Trade. Columbus: Ohio University Press.

Temin, Peter (1988), Product Quality and Vertical Integration in the Early Cotton Textile Industry. Journal of Economic History 48, 4 (December): 891-907. 
HINTON, BARBIERO, KIM The Lessons of the Cotton Mills

Temin, Peter (1990), Product Quality and Vertical Integration in the Early Cotton Textile Industry: A Reply. Journal of Economic History 50, 3 (September): 691-92.

Urquhart, M.C (1986), New Estimates of Gross National Product, Canada, 1870-1924: some Implications for Canadian economic development. In Long Term Factors in American Economic Growth, edited by Stanley l. Engerman and Robert E. Gallman, pp. 9-94. Chicago: University of Chicago Press.

Urquhart, M.C (1993), Gross National Product Canada, 1870-1926: The Derivation of the Estimates. Kingston and Montreal: McGill-Queen's University Press.

United States, Bureau of the Census (1976), The Statistical History of the United States from Colonial Times to the Present. New Yory: Basic Books.

Williams, Glenn (1979), 'The National Policy Tariffs: Industrial Underdevelopment through Import Substitution.’ Canadian Journal of Political Science 12, 2 (June): 333-68.

Young, John H (1957), Canadian Commercial Policy. Ottawa: Queen’s Printer. 